\title{
SALT, HISTORY AND CULTURE IN THE WESTERN GRASSLANDS OF CAMEROON
}

\author{
Kah Henry Kam* \\ http://dx.doi.org/10.4314/og.v13i 1.1
}

\begin{abstract}
This paper examines the socio-cultural value of salt among the people of the western grasslands of Cameroon from the precolonial era to contemporary times. Salt was andremains an important condiment used in households, marriages, treatment of the sick, initiation and other cultural ceremonies throughout the western grasslands and elsewhere in Cameroon. It was a priceless and rare commodity in the past and explains the high value that was attached to it by all and sundry. It also played a cutting-edge role in the political economy of many ethnic groups across Africa from production to commercialisation. Young people from different ethnic groups in the western grasslandsundertook long and tedious journeysto sell different commodities like kernels and mats and in return bought this scarce and precious commodity for retail or various socio-cultural uses. Important village notables and traditional rulers stored salt in locally made containers and made it available when this was needed. Salta once very scarce commodity is in abundance today. One no longer needs to trekfor days, weeks and months to procure it as was the case in the pre-colonial and colonial past. Many njangi or local spent thrift societies buy the condiment in huge quantitiesand distribute to members during the end of year for use infestivities like Christmas and New Year. Family heads also keep and give their kith and kin some of itas a responsibility. Through a content analysis of existing literature, interviews and observations, this paper probes into the history and cultural meanings and uses attached to this important condiment in the western grasslands of Cameroon known for its very rich and diverse cultural practices.
\end{abstract}

Keywords: Salt, Cameroon, Grasslands, Culture, Ritual 


\section{Introduction}

The importance of salt in regional trade, dowry payment, seasoning, trade currency, wedding rituals, gift to nursing mothers, appeasement of a discontented party, royal privileges among others cannot be over emphasised (Kah 2006: 1-3; Kah 2016: 60; Afigbo 1973: 86; Diagne 1992). ${ }^{1}$ Diagne (1992: 40) maintains that salt was an essential item in regional trade on the Guinea and Equatorial coasts in the $16^{\text {th }}$ century under Portuguese hegemony. It was also a vital item in the early regional trade in central Tanzania and throughout Ethiopia in East Africa. The Kongo kingdom and other neighbouring kingdoms in central Africa traded in salt as part of regional trade. The significance attached to salt trade was because among other things, it was a requirement of life and expressly to people who lived mainly on vegetable foods (Ochieng 1992: 838839; Haberland 1992: 709; Vansina 1992: 547).Arabs were intermediaries in the salt trade between the North and West Africa during the pre-colonial period (Falola 1992; Perinbam 1996).

While a lot has been written on the politico-economic importance of salt in different African regions since the pre-colonial period, this paper broadens the historiography of this condiment to deliberate on itssocio-cultural import. This is done by taking into accountthe culturally diverse and rich western grassland region of Cameroon. Its people were very mobile as recorded in the history of migration in Cameroon dating back to the period of general migration of ethnic groups in Cameroon to settlement. This paper thus contends itself with an examinationof the history and sociocultural importance of salt in the western grasslands which is today known as the North West Region of Cameroon. The North West Region prides itself with great and richsocio-culturalactivities in Cameroon. The people are a proud defender of their culture wherever they are. They equally perform different and symbol rich rituals to valorise this culture. Cameroon's western grasslandsisgenerally located at an altitude of 1000 to $3000 \mathrm{~m}$ above sea level. It is also an area of ethnic and cultural diversity

${ }^{1}$ File No 512, Af 4, Assessment Reports, Anyang-Manta Tribes Mamfe Division British Southern Cameroons, National Archives Buea, (NAB); File No. Af 15a, Report on the Bangwa Area 1942, NAB. 
characteristic of the cultural heterogeneity of Cameroon (Pelican: 2012: 166).Cameroon has over 280 ethnic groups according to linguistic classification.

In spite of the fact that indigenous salt production declined in Africa during the colonial period in Ada in the Volta River area of West Africa indigenous salt production resisted the negative impact of colonial rule (Williamson 1956; Sutton 1981: 43; Maier 1986; Yankowski2007: 24-47).Salt trade was also flourished between the Cross River basin and the grassland communities of Cameroon. The Banyang for example were intermediaries between the salt producing villages like Baje and Mbakang in the Cross River basin and the grassland communities especially those that were neighbouring the Cross River (Kah 2006: 3) and shared a similar language. In the grasslands of Cameroon, the early commercialisation of salt was ably regulated by royal households. This made salt trade to be known as royal trade. Much of it was preserved in long bars and disposed of whenever the need arose (Nkwi 1987: 117-118). The direct involvement of the royal household in salt business clearly shows that salt was important. It also shows that it was an essential and scarce commodity which needed regulation to benefit the highly placed in society as well as those who belonged to the lower rung of the social ladder.Other commodities were used in exchange for salt because of its sociocultural and even economic and political significance. Different ethnic groups like the Bamum imported salt from other places (M'bokolo 1992: 519) to serve different uses. In other parts of Africa notably Kebbi in Nigeria, salt was traded with the Nupe, Ilorin and Gwanja people (Laya 1992: 479) and helped create a bond of relationship between them.

\section{Methodology and Significance of Study}

The methodology employed in this study is essentially based on a collection and re-interpretation of data about saltfrom secondary and primary sources. We have also relied heavily on observation, participant observation and discussions with people who have used or benefitted from salt because of their position within the traditional society in the western grasslands of Cameroon. Such people include members of male and female regulatory societies, notables, ritual 
leaders and members of meeting groups. Participant observation offered us the opportunity to get first information about salt and its socio-cultural commitments in the western grasslands of Cameroon.The one-on-one interviews also gave us an opportunity to appreciate the socio-cultural significance of salt not only in the western but also other socio-cultural regions of Cameroon.

Since time immemorial salt has been variously used by different communities or people the world over for medicinal and seasoning purposes. Among the Shuar and Ahuar of the southern Montana region salt was traditionally used for medicinal purposes.Those people who scarcely consumed this condiment among the Shuar and Ahuar of this region of Ecuador were simply considered to be uncivilised (Pomeroy 1988: 147). Such a description was not limited to them because inmany other African ethnic groups' salt was used for various socio-cultural, economic and political reasons. This priceless commodity was regularly used for curative purposes especially by herbalists and other Seers of the society. Salt was also an indelible ethnic marker for some communities indifferent parts of the world. For example, among the Andean groups of Ecuador, salt was a common component of cultural and symbolic dialogue. The people made salt to play an important role in cultural dialogue and other symbolic activitiesin the society. It was also noticed that in the $16^{\text {th }}$ century salt and hot pepper were the principal condiments for the highlanders of Ecuador of Latin America. With pride therefore, the highlanders of Ecuador ate salt and hot pepper as a distinct cultural practice of their own. The inclusion or consumption of salt by the people was an indication of membership in society, social structure and a consideration of taste.

The Spanish who colonised Ecuador soon learnt about the curative use of Ecuadorian salt and actively went for it at two major sites. They participated in its exploitation, commercialisation and use. The salt of the Salinas-Bolivar settlement in Ecuador was particularly renowned because they people believed it cleared obstructions in the body which included a cure forgoiter. Rural people of neighbouring Salinas-Bolivar today are full of praise forSalinas salt because of its medicinal properties. The salt is a preventive medicine for cattle. When cattle and horses are given 
Salinas salt on a regular basis, they stay healthy. This salt also treats human ailments. Among these human aliments are respiratory problems (Pomeroy 1988: 148) which the people greatly appreciate. The Salinas-Bolivar salt was in fact a great cultural marker and the people were proud of this because it made them unique from other people in their use of it.

Some communities gave more value to salt that to gold and this explains the problems that were associated with its scarcity. During World War II, salt generated the greatest upheavals among Nigerians as reported in newspapers such as the West African Pilot and in oral commentary by the citizenry. These upheavals made the colonial government ill at ease. It was aware of the utmost importance of salt in the diets of Nigerians who could not without it (Falola 1992: 412). Its absence was a source of conflict between the colonial authorities and the colonial subjects.In most regions of the world since the pre-colonial period salt is important or highly valued because it is an essential addition to healthy food intake. The transformation of many ethnic groups from a nomadic to an agricultural life was linked to the availability of salt. Salt therefore contributed to the migration of people from one place to another.

During the early stage of human development, salt was a necessity of life and communities blessed with natural salty springs jealously preserved them as gifts from God (Kobe 1958: 61). Other communities could have access to these salty springs only on the acceptance of those that owned them. Some authors like Potts (1984: 225) contend that salt made communities to develop a civilised life so to speak.Soil also contains a relatively small part of the salts ordinarily designated mineral nutrients which are in soluble form (Duggar 1920: 307) and useful to plant growth. Among the Mande of West Africa, salt played an important role in social stability, lineage continuity and harmonious gender relations (Perinbam 1996: 273). Salt was not only an important trade commodity across the Sahara Desert into the Middle East but also an important commodity that promoted social interaction and peace among Mande society in West Africa.Through its exploitation, use and sale, salt also promoted gender interactions.

The socio-cultural importance of salt cannot be undermined in many African communities. Among the many Africans in villages 
who consume vegetables rich in potassium and low in sodium, they have a craving for salt because it adds flavour to their meals. Children consume small amounts of salt even when this is not very good for their health. Among the Cewa people it is believed that salt addsaroma to food and also serves as a vehicle for the transmission of a dreaded skin disease, mdulo (Williamson 1956: 82). This disease manifests itself in swollen faces, wrists and ankles. Other symptoms of the disease are persistent cough, great weakness and waste which often result in the death of affected persons. Women during menstruation were prevented from adding salt to food because it was believed that if they did this they would harm all those who ate the food. Many Cewa women jealously respected this tradition or cultural belief.

Besides, a woman who engaged in illicit intercourse would inflict mdulo on her husband if she put salt in his ndiwo (food). Salt was therefore used among the Cewa to prevent adultery. A man, who however received unsalted ndiwo, blamed the wife for being guilty of wrongdoing. Women became very cautious and made sure they provided their husbands with salted ndiwo in order not to be accused or suspected by their husbands. Similarly, men who went to produce or collect salt were not expected to have sexual intercourse and no man was to eat salt that had not been tasted. Other men who bought salt to retail in the village usually gave everyone a small quantity to taste before buying it. Salt became a source of camaraderie and love among people of the same community. People who wanted to protect themselves from diseases caused by salt bought medicine from the tribal doctor at an exorbitant price (Williamson 1956: 8587). These people were therefore careful not to acquire a salt related disease in order not to buy medicine from a tribal doctor. The production and procurement of salt had a culture of its own.

\section{Production and Procurement of Salt}

Salt production in sub-Saharan Africa has a long history. The production of this condiment generally followed the same pattern in the communities that produced it although there were differences in method. The production process generally rotated around leaching salt-rich material like soil or plant ash to make brine and then reduce it into crystalline salt. The resultant brine was reduced to salt by 
means of slow boiling over an open fire. In some communities, boiling vessels were a little more than moulds. These moulds were destroyed to remove the salt after a single use (Antonites 2013: 106).Prior to the advent of colonial rule among the Cewa (Chewa)of Nyasaland (now Malawi), local salts were produced from various earths. In the Kota Kota District for example, the earth around the lake was used to produce salt which was distributed throughout the Kasungu District in the 1940s. Women were also deeply involved in the preparation of salt (Williamson 1956: 83) meaning that salt production was gender inclusive. Salt was also extracted from salt rocks, brine springs and from sea water in part of Asia (Yankowski 2007: 24).

Meanwhile in some parts of West Africa, water was carefully channelled into shallow ponds. The water was then evaporated in the heat of the sun and what remained on the ground after evaporation was a thick salty crust. This salty crust was then scrapped and purified by mixing it with warm water. After the mixing, it was poured through cone-shaped baskets which were filled with straw. This was then re-dried in the sun to obtain the much needed salt (Fyfe 1968: 239) for several uses. In other parts of the regionwhich were not blessed withmarine salt, the people cultivated grasses or reeds with a high saline content on plots in marshes or rivers to obtain salt. Thereeds were eventually harvested in the dry season, burnt and their ashes were leached to collect potassium salt. In marine settlements, sea salt was collected through natural evaporation from sea-pans or by boiling sea water (Vansina 1990: 86; Fanso 1989: 63). In Igboland in Eastern Nigeria, bitter herbs were used in place of salt but later on the people started burning grass and dissolved the ashes in water. The solution was then evaporated over low fire to obtain salt (Afigbo 1973: 68).

Several other ethnic groups of Africa were involved in the production of salt for various socio-cultural and economic reasons. The Nunu and the Ntomba from the $18^{\text {th }}$ century onwardsproduced salt in addition to other economic activities like pottery and sugarcane alcohol for the flourishing Congo River market. Rock and vegetable salt from Mbosi country became a vitally important item which was produced mostly by riverine peoples along the waterways (M'bokolo 1992: 540-541). In addition, the Luo and the Walowa of 
East Africa actively participated in salt-mining because it was one of their most important economic activities and provided them with a means of sustenance. In central Tanzania, most of the people produced small quantities of salt by burning grass or collecting surface deposits since high quality sources were rare. The major exploitable saltpans were found at Ugogo and Ivuna, Kanyenge, Lake Balangida, Singida and Lake Eyasi and at Bukune and Bulungwa south of Kahama. The Bunyuro of Uganda also possessed rich salt deposits. In Kebbi in the Hausa region of Nigeria every producer of salt gave the Kanta as tax one gourd a year (Ochieng 1992: 839; Webster et al 1992: 795; Laya 1992: 472).Salt production was also carried out in the sedentary settlements of Kanembu and Buduma and Borno controlled all easily accessible sources of mineral salts in such places as Muniyo, Bilma and around the Lake Chad region (Barkindo 1992: 512). The production of salt across the length and breadth of Africa clearly showed that this condiment was very important in the daily lives of the people and especially in their political economy.

Salt was locally produced within many areas prior to its importation from other places into the western grasslands. Generally speaking, throughout the savanna region of Cameroon local chieftains were charged with the supervision of the production and sale of this precious and scarce socio-cultural and economic resource (Nkwi 1987: 117-118). In the Kom kingdom, mineral sources that had salt were exploited and kept in segments of bamboos. Similarly, there was an important mineral salt deposit at Bamessing in Ndop which was exploited by the people for the community and other groups. Neighbouring Bamunkawas also involved in the production of its own salt from vegetable sources. This was carried out in the immediate pre-colonial era (Fowler 1990: 410-411).

The procurement of salt for various socio-cultural uses in the western grasslands of Cameroon came from two principal directions. The Akwana salt came from the north through the Kom Kingdom into other parts of the western grasslands. The salt was also brought into the area through several Nso intermediaries. In spite of the argument that the presence of salt in the Kom kingdom was the Akwana salt from the north, some Kom informants however argued that their first salt came all the way from Bagham and Bamendjinda 
in the eastern grasslands. The transportation of salt from these two directions into the western grasslands was black and wrapped in leaves.

Salt also came into the western grasslands from the South and West. The one from the South was collected from the Cross River salt springs. The middlemen who facilitated the trade from the South and West into the western grasslands were from Bali Nyonga, Banyang villages, Bagham and Bamileke villages. Some communities however produced vegetable salts and some limited mineral salt deposits (Fowler 1990: 409; Kah 2006). The salt that came into the western grasslands from the South found its way into Babungo through Bangolan traders who got it from Bagham and northern Bamileke chiefdoms through exchange with cowries. Baba traders also used Babungo iron wares in exchange for salt in Bamendjinda. They then traded the salt so obtained for cowries from the Nso and Oku people. Other traders from the Ndop plain chiefdoms such as those of Bamunka and Baba travelled to the northern Bamileke chiefdoms and Bagham where they bought salt and exchanged it with cloth from Nso. The cloth was again sold at these Bamileke chiefdoms and Bagham where more salt was bought for sale to the Nso. Apart from salt coming into other western grasslands region from the Bamileke chiefdoms, salt also came through Bali Nyonga. It was sold for brass rings to traders from BabankiTungo and then to Bamessing where it was likely bought with cowries (Fowler 1990: 410). The procurement of salt for the fondoms of the western grasslands of Cameroon was made possible by numerous traders and intermediaries who made a leaving out of this relish. Salt played a very important role in the socio-cultural life of the people of the western grasslands of Cameroon in particular and other communities in the world.

\section{Socio-Cultural Importance of Salt}

In the production of caerphilly-type cheese from cow's milk in the western highlands of Cameroon by the Fulani and some other indigenous people, salt is one of the condiments (Mendi et al 2000). Following a funeral performance or any joyous occasion young people in the western grasslands of Cameroon shared out the salt and other gifts collected or given to them as part of the general 
entertainment by the families concerned. Within the Laimbwe ethnic group of Menchum and Boyo Divisions of the North West Region for example, the mezhuuh masquerade which consisted of young boys usually performed during funeral ceremonies and among the things given for their entertainment was salt, corn fufu and vegetables or any other available sauce.After performance, they ate and distributed the salt given them. The criterion used was seniority of members of the mezhuuh.

Similarly, within the western grasslands of Cameroon there is a longstanding tradition of credit-rotating meetings or njangis, the buying and sharing of salt to members towards the end of the year.This was occasioned by the fact that salt was a very scarce and expensive commodity during the pre-colonial and part of the colonial periods. Many people therefore decided among other reasons to get together, purchase and share this precious household condiment. Large quantities of salt were bought so that people could go home a good quantity as to serve them for a long period. Since the priceless commodity was often scarce, members of these creditrotating meetings travelled long distances to procure it for the members. The salt was very useful during the end of year festivities like Christmas and New Year.This was because relatives and in-laws were given some quantity of the commodity. The practice of purchasing and distributing salt by njangi groupsis more or less enshrined in the by-laws of these groups. It is now a very widespread practice in many villages of this region of Cameroon. Today, meetings compete with one another in the quantity of salt bought for their members. The more salt a meeting buys the greater its chances of having new members at the start of a new year.

In the distant and recent past, when some peopleacquired great quantities of salt like among the Babungo people of the Ndop plain of the western grassfields, it brought a stream of kin and neighbours to beg for it. Salt became a great uniting force and created a community spirit among those who had it and those who relied on them to have and use it. A bulk quantity of the condiment also facilitated its use in regional trade in exchange for slaves destined for the coast where slave merchants were stationed. In Bali Nyonga, bundles of salt packed in large conical baskets were exchanged for slaves. Two of these baskets were equivalent to a 
slave (Fowler 1990: 409-410). Salt was therefore so important that some people lost their freedom because they were given out in exchange for it. This also indicated that some wealthy people gained a higher social status in society because they were able to procure or retailed it to others. Among the Bambui people of Mezam Division, salt was one of the important items in the payment of bride wealth. This was eventually distributed among family members The other items were and still include money, farm labour, wine, oil, firewood, food items, household utensils and clothing (Amungwa 2015: 21). This condiment therefore plays a key role in marriage arrangements and in the establishment of strong ties between different families.

Among the Babungo therefore, the possession of salt made people to develop or sustain the culture of sharing and redistribution to the have-nots. Salt therefore enhanced the communal spirit of" all for one and one for all." People's generosity or selfishness was measured by their willingness to share the scarce commodity with other people. Slavery as an important social institution within the different fondoms of the western grasslands was also promoted or sustained through the ownership of a bulk quantity of the condiment. Wealthy people through regional trade kept or elevated their social status by exchanging it for slaves. These slaves further enriched them through their unpaid labour services in the farms, long distance trade and other businesses. Salt therefore served both an economic purpose through trade and also perpetuated the slavery institution in many communities. It also culturally boosted many ethnic groups of the western grasslands such as those of the Ndopplain chiefdoms, Bali Nyongaand others that were involved in the salt business because they could use it for various cultural activities and to create strategic alliances for themselves.

Among the Bamileke of the eastern grasslands of Cameroon, the traditional Priest offered sacrifices of salt among other items like oil, meat and palm wine to the 'gods' or the Supreme Being through the agency of spirits and ancestors. They performed this sacrifice to ask for God's help following the birth of a child. This sacrifice was also performed when someone took ill, when a woman could not conceive a baby or when a traditional seer purportedly received a message that a propitious moment had arrived (Schrag 2004: 7).Similar sacrifices that involved the use or consumption of salt 
were and are still being carried out by many diverse ethnic groups of the western grasslands of Cameroon. When sacrifices or ritual activities were organised in appreciation of birth, in honour of the dead and other related activities, salt was always one of the items used demanded for and used.A traditional Priest was always on hand to carry out this ritual. In other cases, the family or lineage heads performed them and still in others, it was the traditional regulatory society such as the nwerong, ngumba and kwifon among the Nso, Bali and the Tikar speaking villages of the western grasslands.

The Laimbwe of the North West Region usually trekked for days to Nkongsamba in French-speaking Cameroon during the Mandate and Trusteeship periods to sell mats. In return, they bought salt and helped one another to transport it over hundreds of kilometres to the village. They invested in this because salt was an unforgettable item in bride wealth among the people (Kah2013: 62).Besides, the Noni people of Bui Division in the western grasslands paid tribute to the Fon of Nso in the form of leopards, lions, tigers and hyenas during the pre-colonial period. In return for Noni subservience, the Fon of Nso gave them among other things salt. The salt was sent to the Fon of Noni. The other items which the Noni people got from the Fon of Nso included palm oil, caps, clay pipes, guns, cloth and other rare goods (Nfi 2014: 64).Salt was therefore used to cement diplomatic as well as servant-master relationship.

In Menchum Division, northwest of the North West Region of the western grasslands, salt was one of the important items that were demanded for initiation into social clubs, the regulatory societies and in the payment of bride wealth. The other items apart from salt were palm oil, (Tem and Nyoh 2013: 22) a precious commodity for households. People from around KatsinaAla River made available this salt acquired from Nigeria for use in marriage and initiation ceremonies (Tem and Nyoh 2013: 23). In Nso among other things, men were responsible for providing salt to members of their families (Chem-Langhee 1995: 179). This was probably because as a scarce commodity, they would go for it to satisfy family members. Among the Yamba of the Donga Mantung Division of the North West Region of Cameroon salt giving was also part of the marriage payments (Gufler 1995: 97). This payment was not 
limited to the beginning but throughout marital life. This was similar to what obtained in other ethnic groups of the western grasslands.

Salt also played an important role during death celebrations that were and are still organised in many parts of the western grasslands of Cameroon. Among the Laimbwe people of Menchum and Boyo Divisions, a bag of salt is traditionally equals to a goatwhen entertainment is given to the kuiifuai regulatory society for the death of its member. Family members were and are still being taxed to facilitate the availability of material and entertainment of members of societies to which the late person belonged. Apart from salt other items provided for entertainment include goats and pigs. The quantity left is then distributed and taken homeby members of kuiifuai. Members of a higher grade get more salt than those of the lower grade.Usually, members of the ikuum society, the apex lodge of kuiifuai, go home with a greater quantity of salt, followed by those at the kooh lodge and then those that are not yet in the kooh lodge in descending order.

Ordinary members of the regulatory society usually go home with the smallest quantity of the condiment. This is to encourage them to seek membership into higher grades of the society. When salt is given for general entertainment of the villagers, whoever is present is given a quantity of it to carry it home. In addition, masquerades perform during the funeral of a member and are given a bag of salt if the family of the bereaved isunable to provide a goat for entertainment. Members of differentmasquerades benefitted. The salt is distributed among them for home use. The more salt members of regulatory societies get from entertainment during funeral ceremonies, the longer they will not buy salt. Generally, during memorial services or final death celebrations in the dry season that lasts from December to March, many members of regulatory societies and masquerade or juju societies get a lot of salt and may go for the whole year without buying it.

Salt is an important condiment for roasted fowls during death celebrations or other ritual activities in many parts of the western grasslands of Cameroon in general and Laimbwe ethnic group in particular (Kah 2016: 60). At the death of someone, the family presentsfowls to different social groups for their entertainment. Among the different groups that receive fowls in 
appreciation for supporting the bereaved family include the grave diggers, carpenters and the groups to which the dead person belonged. Besides, during fertility related rituals among others, fowls are roasted and seasoned with salt. After young boys roast fowls over a makeshift fire-place, it ispieced into smaller parts and put into a bowl with salt and oil totaste. The bowl was made of clay in the past but today a dish is used instead. A lot of salt is added to the roasted fowl and a little quantity of oil. Salt makes a roasted fowl taste well. Little children havealso cultivated the culture of eating pepper with salt and corn fufu. There was once a misleading impression that those who ate salt and pepper became intelligent at school. Although this was thethinking in the past, insome rural areas of the western grasslands today, school children still think that eating pepper with salt makes one intelligent at school. Salt is therefore not only important whenadded to a roasted fowl but it is also thought among children and wrongly that it makes them intelligent at school.

Many traditional healers across the western grasslands demand payment for the servicesthey render in salt and other items notably cutlasses, blankets, fowls and money. When they treat more people they receive more salt and other items in returnin payment. When they accumulate more salt, they share some of it to family members and friends or sell it for additional money. The traditional herbalists, many of whom are inundating the towns do not only ask salt in payment for treating patients in addition to other items, but also use this condiment to prepare medicines or concoctions of herbs and other material for their clients, a good number of them politicians seeking for influential positions in society or poor citizens who cannot afford to pay for hospital bills when they fall sick. They add salt to these concoctions to taste so that patients can easily consume them.

In addition, initiation into social clubs and other groupswithin ethnic groups in the western grasslands of Cameroon include salt as contribution. In the Laimbwe villages for instance, salt is used during initiation into the tschong or friction drum society (Kah 2015: 151; Kah 2016: Forthcoming). Other social clubs demand salt as one of the pre-conditions for membership. At the death of their member salt is also given as an item of entertainment. 
The condiment is also used in the charms and medicines which these clubs and groups use. Salt is therefore one of the requirements for admission into some clubs or groups. The efficacy of the charms, it is also generally agreed, would be a failure if salt is not added to them.

Hunters and trappers of game also use salt to seasoning meat in preparation to sell or preserve it for future use. When a hunter kills an animal in the rainy season, he needs to season it for the market or some other future use. This seasoning is done with salt and the meat placed over a fire-place to dry and prevent it from decay. Trappers of gameon the other hand use salt to attract animals to the trap. Many other people who keep or rear goats always buy salt togive and domesticate them. Salt has therefore become a veryusefulcondiment to hunters, trappers and those who keep domestic animals for various uses. Elderly people in Laimbweland use topreserve salt in special containers for these purposes. They also kept the family together through the occasional gathering and distribution of salt to members in family compounds. Children who are invited by their fathers or family heads to get salt is often to recognise and appreciate them for the support they give them like in the cultivation of crops.It is also considered responsible behaviour by fathers and family or lineage heads.Salt is traditionally stored in special containers in the western grasslands in general and among the Laimbwe speaking people in particular. These containers were Indian bamboos and locally known among the Laimbwe as Pheh'tomtom (sing.). Below is a picture of two of these Meh'tomtom (pl.) where salt was preserved by elders in Bu village for very long periods. The containers were often stored in a dry place in the house or on the Uta'ahghe, an elevated place over a fire place used for preservation among the Laimbwe of Cameroon. (See Picture) 
Figure 1: Meh'tomtom used to Preserve Salt among the Laimbwe

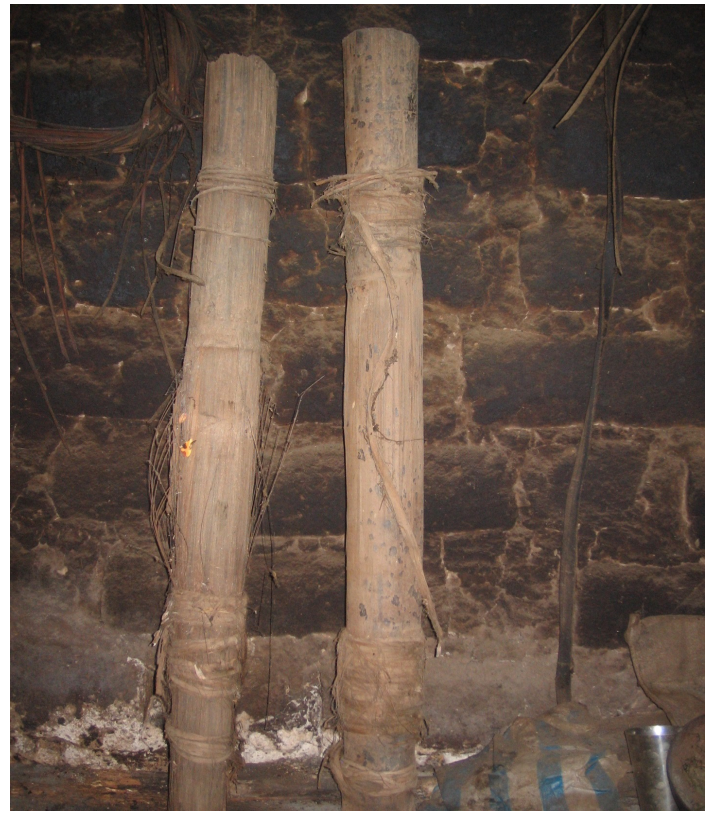

Source: Authors Collection 2015

From figure I above the Meh'tomtomare elongated. Ropes are fastened to them for easy transportation from place to place. In the past Laimbwe fathers would for example go to funeral celebrations with their children carrying one of these Pheh'tomtom with salt. The salt was meant for the bereaved family. This was used in preparing soup for the death celebration. Salt was a very scarce commodity and when one went with a Pheh'tomtom of it, this was greatly appreciated by those responsible for the funeral celebration. Part of it was used during the funeral ceremony of the dead person and the remainder preserved for use in a future funeral or other activity.

\section{Conclusion}

In this paper we examined the socio-cultural importance and uses of salt in the western grasslands of Cameroon.We began the paper byexamining the importance of salt to different people the world 
over at different historical moments.Salt in fact played a very important role in the long distance trade that took place between the grasslands and other parts of Cameroon and beyond. It brought communities together and kept the community spirit alive. We also examined in this paper, the processes of salt production and associated rituals in different parts of the world in general and Africa in particular.

Salt played an important role not only in the socio-cultural but also the political economy of many of the chiefdoms of the western grasslands. It at one time served as a medium of exchange and also consolidated kinship ties between people of the same geographical environment. The condiment was scarce and yet important which explained why those who possessed it could purchase slaves with it. Others used salt to facilitate initiation into regulatory societies and pay for the bride wealth of their wives. Parents-in-law therefore held in very high esteem the sons-in-law who travelled long distances to buy salt as part of thebride wealth. Upon receiving it, they shared some of it to their children and family members. Some of it was also used during funeral ceremonies for family members. Salt was and remains a condiment of friendship and of great socio-cultural significance in this region of Cameroon.

*Kah Henry Kam, University of Buea, Cameroon, Email: henry.kah@ubuea.cm;ndangso@yahoo.com 


\section{References}

Afigbo, A.E. 1973. "Trade and Trade Routes in Nineteenth Century Nsukka."Journal of the Historical Society of Nigeria (7): 7790.

Amungwa, AnthanasiusFonteh. 2015. "African Cultures at the Crossroads: An Ethnographic Analysis of the Bambui People of North West Cameroon." Advanced Journal of Environmental Management 2 (1): 17-27.

Antonites, Alexander. 2013. "Archaeological Salt Production at the

Baleni Spring, Northeastern South Africa." The South African Archaeological Bulletin 68 (198): 105-118.

Barkindo, B.M. 1992. "Kanem-Borno: Its Relations with the Mediterranean Sea, Bagirmi and Other States in the Chad Basin." In General History of Africa V: Africa from the Sixteenth to the Eighteenth Century, edited by B.A. Ogot, 492-514. California: Heinemann.

Chem-Langhee, Bongfen. 1995. "Slavery and Slave Marketing in Nso in the Nineteenth Century." Paideuma: MitteilungenzurKulturkunde (41): 177-190.

Diagne, P. 1992. "African Political, Economic and Social Structures during this Period." In General History of Africa V: Africa from the Sixteenth to the Eighteenth Century, edited by B.A. Ogot, 23-45. California: Heinemann.

Duggar, B.M. 1920. "The Use of "Insoluble" Salts in Balanced Solutions for Seed Plants."Annals of the Missouri Botanical Garden 7 (4): 307-327.

Falola, Toyin. 1992. "Salt is Gold:" The Management of Salt Scarcity in Nigeria during World War II." Canadian Journal of African Studies 26 (3): 412-436.

Fanso, V.G. 1989. Cameroon History for Secondary Schools and Colleges Vol. I: From Prehistoric Times to the Nineteenth Century. London: Macmillan.

Fowler, Ian. 1990. "Babungo: A Study of Iron Production, Trade and Power in a Nineteenth Century Ndop Plain Chiefdom (Cameroons)." Ph.D Thesis, University College London.

Fyfe, C. 1968. "West African Trade A.D. 1000-1800." In A Thousand Years of West African History, edited by J.F. Ade Ajayi, 238-252. Ibadan, Nigeria: Ibadan University Press. 
Gufler, Hermann. 1995. "Yamba Marriage Systems and Spouses and their Offspring between Protection and Affliction." Anthropos 90 (1/3): 89-108.

Haberland, E. 1992."The Horn of Africa."In General History of Africa V: Africa from the Sixteenth to the Eighteenth Century, edited by B.A. Ogot, 703-749. California: Heinemann.

Kah, Henry Kam. 2006. “A Priceless Commodity: The Politics of Salt Production and Commercialisation in the Cross River Basin of Cameroon 1916-1961." African Study Monographs 21 (1): 1-13.

Kah, Henry Kam. 2013. "Gender and Livestock Farming in Laimbweland, Cameroon 1980s- 2011." Journal of Sustainable Development in Africa 15 (1): 56-72.

Kah, Henry Kam. 2015. The Sacred Forest: Gender and Matriliny in the Laimbwe History c. 1750-2001. Munster: Lit Verlag

Kah, Henry Kam. 2016. "The Laimbwe Ih'neem/Ritual Ceremony, Food Crisis, and Sustainability in Cameroon." Journal of Global Initiatives: Policy, Pedagogy,Perspective 10 (2): 5370 .

Kah, Henry Kam. 2016. "Ritual Use of Currency in Laimbwe History, Cameroon." Journal for Studies in Humanities and Social Sciences (Forthcoming).

Kobe, Casal U.A. 1958. "Salt."MonumentaNipponica 14 (1/2): 6190.

Laya, D. 1992. “The Hausa States.”In General History of Africa V: Africa from the Sixteenth to the Eighteenth Century, edited by B.A. Ogot, 453-491. California: Heinemann.

Maier, D. J. E. 1986. "Colonial Distortion of the Volta River Salt Trade."African Economic History (15): 13-37.

M'bokolo, E. 1992."From the Cameroon Grasslands to the Upper Nile."In General History of Africa V: Africa from the 
Sixteenth to the Eighteenth Century, edited by B.A. Ogot, 515-545. California: Heinemann.

Mendi, Stephen D.; TikuKamga Pamela and Imele Helene. 2000. "Adapted Technology for Small-Scale Manufacture of Caerphilly-type Cheese from Cow's Milk in the Western Highlands of Cameroon." The Journal of Food Technology in Africa 5 (4): 120-122.

Nfi, Joseph. 2014. "Intercommunity Relations and the Politics of Identity in the Nso Chiefdom BamendaGrassfields, Cameroon." Journal Research in Peace, Gender and Development 4 (4): 63-69.

Nkwi, Paul Nchoji. 1987. Traditional Diplomacy: A Study of InterChiefdom Relations in the Western Grassfields North West Province of Cameroon.Department of Sociology, University of Yaounde.

Ochieng, W.R. 1992. "The Interior of East Africa: The Peoples of Kenya and Tanzania, 1500-1800.'In General History of Africa $V$ : Africa from the Sixteenth to the Eighteenth Century, edited by B.A. Ogot, 828-848. California: Heinemann.

Pelican, Michaela. 2012. "Friendship among Pastoral Fulbe in Northwest Cameroon." African Study Monographs 33 (3): 165-188.

Perinbam, B. Marie. 1996. "The Salt-Gold Alchemy in the Eighteenth and Nineteenth Century Mande World: If Men Are its Salt, Women Are its Gold." History in Africa (23): 257-278.

Pomeroy, Cheryl. 1988. "The Salt of Highland Ecuador: Precious Products of a Female Domain."Ethnohistory 35 (2): 131160.

Potts, Daniel. 1984. "On Salt and Salt Gathering in Ancient Mesopotamia." Journal of the Economic and Social History of the Orient 27 (3): 225-271.

Schrag, Brian. 2004. "Musical Invigoration of Cultural Dynamism in a Bamileke Dance Association." Yaounde: Ministry of Scientific and Technical Research. 
Sutton, I.B. 1981. "The Volta River Salt Trade: The Survival of an Indigenous Industry." Journal of African History (22): 4361.

Tem, Protus Mbeum and Hyasinth Amih Nyoh. 2013. "War, Skirmishes and Socio-Economic Activities in Pre-Colonial Menchum ca. 1740 to 1902: Factors for Inter-Ethnic Relations." Global South 9 (3): 19-25.

Vansina, J. 1990. Paths in the Rainforests: Toward a History of Political Tradition in Equatorial Africa. London: James Curry.

. 1992. "The Kongo Kingdom and its Neighbours." In General History of Africa V: Africa from the Sixteenth to the Eighteenth Century, edited by B.A. Ogot, 546-587. California: Heinemann.

Webster, J.B., B.A. Ogot and J.P. Chretien. 1992. "The Great Lakes Region, 1500-1800." In General History of Africa V: Africa from the Sixteenth to the Eighteenth Century, edited by B.A. Ogot, 776-827. California: Heinemann.

Williamson, Jessie. 1956. "Salt and Potashes in the Life of the Cewa." The NyasalandJournal 9 (1): 82-87.

Yankowski, Andrea. 2007. “Asinan: Documenting Bohol's Traditional Method of Salt Production and the Importance of Salt in the Region's Early Economy." Philippine Quarterly of Culture and Society (35): 24-47. 